\title{
POLICY AND GOVERNANCE
}

\section{ational integrity systems in small Pacific island states}

Peter Larmour Manuhuia Barcham $05-9$

Asia Pacific School of Economics and Government THE AUSTRALIAN NATIONAL UNIVERSITY

http://apseg.anu.edu.au 
The Policy and Governance Program at the Asia Pacific School of Economics and Government publishes a series of Discussion Papers on a range of policy issues, including issues of political institutions and institutional design, accountability and public sector management, and the relationship between political and economic reform. The Discussion Papers disseminate research quickly in order to generate comments and suggestions for revision or improvement. Since they often represent preliminary or incomplete work, citation and use of such a paper should take account of its provisional character.

The opinions contained in the series are those of the authors, and not those of the Asia Pacific School of Economics and Government at The Australian National University.

Peter Larmour <Peter.Larmour@anu.edu.au> is a Reader in the Asia Pacific School of Economics and Government at ANU. Manuhuia Barcham <M.S.Barcham@massey.ac.nz> is Director of the Centre for Indigenous Governance and Development at Massey University, New Zealand.

\begin{abstract}
Studies of 'national integrity systems' are part of the new international concern with corruption and its prevention. Alan Doig and Stephanie Mclvor coordinated studies of 18 countries, and reflected on their method in Public Administration and Development (2003). This article compares their conclusions with an overview of a subsequent study of 12 small island states in the South Pacific using the same method. Though the sample was not chosen with scale in mind, smallness may explain some of the similarities between the Pacific Island cases, particularly the risks associated with offshore financial centres, trust funds and investments. Their relative size and weakness has also made them targets for direct intervention by Australian police and officials to rebuild anti corruption institutions. The article goes on to show how the evidence from the Pacific Island cases raises questions about some of the standard proposals for anti corruption reform: stronger parties, an ICAC, civil society coalitions and greater accountability and transparency.
\end{abstract}




\title{
National Integrity Systems in Small Pacific Island States
}

Peter Larmour and Manuhuia Barcham

\begin{abstract}
Studies of 'national integrity systems' are part of the new international concern with corruption and its prevention. Alan Doig and Stephanie McIvor coordinated studies of 18 countries, and reflected on their method in Public Administration and Development (2003). This article compares their conclusions with an overview of a subsequent study of 12 small island states in the South Pacific using the same method. Though the sample was not chosen with scale in mind, smallness may explain some of the similarities between the Pacific Island cases, particularly the risks associated with offshore financial centres, trust funds and investments. Their relative size and weakness has also made them targets for direct intervention by Australian police and officials to rebuild anti corruption institutions. The article goes on to show how the evidence from the Pacific Island cases raises questions about some of the standard proposals for anti corruption reform: stronger parties, an ICAC, civil society coalitions and greater accountability and transparency.
\end{abstract}

The idea of a 'national integrity system' (NIS) was invented by Transparency international, the anti-corruption NGO. It is pictured as a Greek temple, consisting of a number of pillars - legislature, executive, civil society, and so on - which together uphold integrity, the opposite of corruption (Pope 2000). For TI, studies of national integrity systems identify opportunities for reform. Aid donors and international agencies, who now see corruption as an obstacle to development, fund NIS studies in developing countries. TI's 'national chapters', private consulting firms, and universities interested in research opportunities are ready to carry them out. There are now 52 NIS reports on TI's website, and more are under way (Transparency International 2005)

This article compares the results of two sets of NIS studies. The first covered 18 countries, and was funded by the Dutch government. It was coordinated by TI's Berlin HQ and Alan Doig and Stephanie McIvor from the Teeside Business School. They reflected on the virtues of the NIS approach in Public Administration and Development, arguing that it provided 'depth to any assessment of the causes and consequences of corruption' (2003: 329). The second, modeled on the first, was coordinated by TI's national chapter in Australia, particularly Peter Rooke, and ourselves at the Australian National University. This 'NISPAC' study covered 12 small island states in the South Pacific, and was funded by the AusAID, Australian government's foreign aid agency.

This article identifies some common themes across the 12 NISPAC reports, compares them with Doig and McIvors's conclusions, asks if they are a consequence of the countries' smallness, and questions some of the NISPAC conclusions about 'what is to be done'. 
Doig and McIvor included a mix of countries, large and small, from around the world. The Pacific Islands constitute a more sharply focussed 'region' in several senses relevant to corruption and its prevention. First, they share a common history and, in Polynesia particularly, a culture of deference to chiefly authority. All but one country, Tonga, was brought under colonial rule, and most were decolonised between 19621980.

Second, they form groupings within regional and international organisations that have been pressing 'good governance' on their members. The Asian Development Bank has been pressing public sector reform on its island members. The OCED, though its financial action task force, has been pressing Nauru, Niue, Marshall Islands and Cook Islands to clean up their offshore financial centres (only Nauru remains on its black list of 'non-cooperating countries', Financial Action Task Force 2005). The Commonwealth is less demanding but its Secretariat funds islands officials on an anticorruption training course in Canberra. The Pacific Islands Forum - an organisation of regional governments, including Australia and New Zealand - has been encouraging its island members them to improve their systems of accountability.

Third, they are defined as a region by powerful neighbours. The US influences its former colonies north of the equator through defence agreements and budget support through a recently renegotiated 'Compact of Free Association'. The recently renegotiated Compact now includes stronger, US-based, provisions to audit grants. Australia has begun to intervened directly in the affairs of its neighbours, including its former colonies, PNG and Nauru. In 2003 Australia led a regional assistance mission (RAMSI) of several hundred troops, police and public servants to restore law and order, and rebuild institutions in Solomon Islands. Australian police are now also patrolling the streets of PNG's capital, Port Moresby, though the legality of their immunity from prosecution is the subject of a constitutional challenge. Australian officials are occupying key positions in government departments there, and in Nauru. Each of these interventions has been with the consent of the local government: welcoming in Solomon Islands, where requests for intervention had earlier fallen on deaf ears, and more grudging in PNG and Nauru. In a recent speech to parliament, the Australian foreign minister talked about 'fragile' states in the region, and highlighted the NISPAC studies (Downer 2005: 19).

Fourthly, the region offers a kind of 'natural experiment', in which the reasons for variation in corruption and anti corruption can be identified against a background of similarity. One possible reason is their smallness. It was often argued that Pacific Island states were 'too small', in functional terms, to become independent on their own. Observers from outside the region often argue for some kind of federation, shared institutions, or continued 'free association' with a former colonial power. So smallness is often reached-for to explain present dysfunctions, and regionalism is often offered as an answer. These well-established habits of thinking are readily applied to the problem of corruption. 
The pattern of corruption in the Pacific Islands

The NISPAC found suspicion of ministerial favoritism towards relatives in appointments, contracts and scholarships. There was abuse of ministerial and official travel, and unnecessary travel. Budget processes were distorted by pet projects and what is called, in the Federated States of Micronesia (FSM), 'pitch and catch' where legislators benefit from expenditure they authorise.

The reports found particular sectors and activities like police and customs, more at risk than others. Most reports painted a dim picture of the performance of the public service. In Kiribati and Nauru, the public service was regarded as a kind of welfare system, providing jobs and incomes. In Palau there were frequent exceptions to the rules 'poor administration, bias, abuse and poor accountability'. In Vanuatu the public service was described as 'weak'.

In Solomon Islands there was 'an almost complete disintegration of state capacity', including misappropriation and embezzlement within the public service. The report describes endemic illegal activity and the abuse of discretionary powers in the regulation of natural resource exploitation, like forestry and fisheries licensing, and in the leasing of government land in Honiara, the capital.

These general problems with the public service affected the police the more so. Police are expected to act against corruption, but their own jobs made them particularly vulnerable to it. Reports expressed concern about police competence in Cook Islands, Kiribati and FSM. Police were tempted by corruption in Tonga. In Vanuatu there were particular tensions following the integration of the police with the paramilitary Vanuatu Mobile Force, and several examples of police rebellions. In Solomon Islands a large faction of police led a coup that forced the Prime Minister to resign in 2000, leading to the collapse in law and order and, eventually, the Regional Assistance Mission.

\section{$\underline{\text { Political Corruption }}$}

In every country, except currently Samoa, parliamentary allegiances are fluid, and governments used their powers to create offices, and make appointments to them, to shore up or reward political support. Offering executive positions, and hence salaries and perks, to MPs is a familiar parliamentary tactic throughout the region. It lies behind increases in the size of cabinet in Samoa or the creation of 'Special Advisors' in Tuvalu (later judged illegal). The report on Tuvalu also notes the suspicion that the government appointed a particular MP as Governor General in order to create an opportunity for a by-election it hoped to win. In Kiribati a minority government had recently asked traditional leaders to allow independent MPs to cross the floor and join the government.

Independent or opposition MPs may provide a check on corruption by Ministers, or the public servants they are in charge of. In Tonga, a pro Democracy movement began with attacks on the disbursements of funds by ministers. In Samoa the authors worried that the 'unassailable dominance' of the Human Rights Protection Party in might reduce parliament's ability to oversee the executive. Yet the reports often show government and other legislators closing ranks against outside criticism. 
In Tuvalu visiting Ministers are expected to make gifts to local communities, and several court cases in Kiribati have explored the propriety of gifts of tobacco to leaders - finding it is expected, even required, of visitors, but not of local campaigners (Larmour 1997). In FSM candidates make 'strategic donations'. In Solomon Islands there have been attempts to normalise these payments through socalled slush funds, approved by parliament, but not allocated by civil servants, though these were being chipped away in donor-sponsored public sector reform campaigns.

\section{What is not corrupt?}

The story was not all bad. A consistent finding from NISPAC was lack of corruption in the national judicial systems. In Solomon Islands, in spite pervasive corruption in the public service, the judiciary (for the moment) retained popular approval. However there were breaks in the chain of the judicial process in the public prosecutors office, and the police. The reports also found electoral administration to be generally clean in spite of the absence of independent electoral commissions in most countries. Yet candidates everywhere found themselves under pressure to provide favours to constituents in return for votes.

\section{Is it Growing?}

The reports are quite precise about the periods when corruption was bad. The Solomons report says serious public service corruption began in the late 1980s and has continued until the Australian-led military and police intervention in. Others describe periods when corruption was worse than it is now - Vanuatu in the 1990s, Samoa until the late 90s and Palau in the period 1979-84. This precision about dates suggests that corruption is not something endemic or inevitable, but the particular and perhaps reversible product of historical circumstances. The Samoan authors report the editor of the local newspaper saying bluntly 'corruption has decreased'.

\section{$\underline{\text { Checks and Balances }}$}

The NIS model sees institutions providing checks against corruption in each other. The idea of 'checks and balances' underlies constitutions modeled on Westminster and Washington. Among the NISPAC countries, there were seven parliamentary executives and two Presidential systems, two hybrids (Kiribati and Marshall Islands), and one monarchy (Tonga, where the King selects Privy councilors whom then automatically become members of parliament).

However, the differences between 'Westminster' and 'Washington' based systems did not seem very great in relation to corruption. There were similar tensions between auditors general and the legislature and in the use of public service appointments to gain political support.

The NIS points to pillars' tasks of policing themselves. The legislature is vulnerable to its own forms of corruption, such as travel funds in Palau. There no leadership codes in Cook Islands and FSM. In Tuvalu the Attorney General's office is working on a Leadership Code. The Pacific Islands Forum has attempted to provide a regional 
standard, but an early detailed draft was replaced by something much vaguer. Solomon Islands, ironically, has an elaborate code, and a Leadership Code Commission to monitor it. However it has not exercised its powers, partly because of under-resourcing, but partly because of its own non-confrontational style of leadership (Larmour 2000).

\section{$\underline{\text { Independent Offices }}$}

The NIS model celebrates independent offices. In every country, government auditors played a very important role in generating information about poorly managed public expenditure, in general, and corruption in particular. Their oversight role was often limited by the weakness of parliamentary accounts committees, which failed to read, debate or act on their reports. In Kiribati, \$20-30 million were found unaccounted for, but parliament had not debated the report. Similarly, Vanuatu's parliament was not reading or responding to audit reports.

Legislatures, however, were vigorous in objecting to the appointments of auditors who criticized them. In Samoa in the 1990s they had turned on the Sua Rimoni Ah Chong, who came from the private sector, and whose reports were highly critical of some ministers. There was intense conflict between the auditor and the legislature in Palau over criticisms of congressmen's use of travel funds.

Concern over misuse of the first round of compact funds led the US to create a special office of the US General Accounting Office, based in Hawaii, to oversee expenditures from the new compacts. The New Zealand auditor general audits Niue's accounts.

Ombudsmen, set up to deal with citizen complaints against government, were rarer than auditors. Where these offices did exist, they seemed relatively invisible and ineffective. Samoa had had an ombudsman since 1988 but the NISPAC report found not much publicity about its role. A Commissioner for Public Relations in Tonga had 'so far made little impact'. The Cook Islands report quotes an earlier Political Review Commission finding a 92\% dissatisfaction rate with the work of the Ombudsman set up in 1984 (though from a tiny sample of self selected respondents).

In any case, waiting for complaints may not be the best way of uncovering corruption. The big exception was Vanuatu, where the ombudsman also had the responsibility of investigating leadership matters and recommending prosecution, a task vigorously taken on by the first incumbent, Marie-Noelle Ferrieux Patterson in the 1990s. So vigorous was her reporting that the legislature rescinded the legislation setting up her office, which was already provided for in the constitution. However few, if any, of her reports were acted upon. She was replaced by a quieter figure.

The NISPAC researchers followed a questionnaire used by Doig and McIvor, but we added questions about culture, which is often cited as a cause of corruption in the region, an excuse for corrupt behaviour, or an impediment to doing something about it. Questions were also asked to about corruption within the private sector and NGOs. 


\section{$\underline{\text { Culture }}$}

Several NISPAC reports pointed to difficulties of translation, or to broader disagreements about what counted as corruption, and the seriousness with which it mattered. The Tonga report found 'lack of consensus' about what counts as corruption. In Vanuatu, for example, the word, and concept tended to be applied to bad behaviour in non-traditional urban contexts. The report found ambivalence and 'lack of ownership', and many people did not think it mattered much. Some people saw particular political manoeuvres as corrupt. Some saw public and private morality as continuous, including 'personal as well as professional indiscretions' (Solomon Islands). In Vanuatu an unwelcome, but otherwise innocent, new tax on bank withdrawals in Vanuatu was criticised by some people as corrupt.

Visible petty corruption - routine small payments for services rendered - was only a problem in a few countries (Samoa, Tonga and Palau). Reports and court cases are typically seen as the tip of the iceberg. More may be taking place than is ever found out. Yet perceptions may work both ways. Where people are suspicious of neighbours, or foreigners, or jealous of their success, they may see more corruption than there is.

Many reports described reluctance to act when corruption had taken place. The issue here was not relativism, or different understandings. It was more that people were fearful of intimidation, or reluctant to rock the boat by public criticism. Some seemed simply forgiving, particularly of kin. These cultural factors were not causing corruption to happen, but rather allowing it to continue unchallenged.

Several countries formalise traditional leadership in various kinds of national councils of chiefs. The reports did not find much evidence of corruption among these organisations. Nor did they seem to be playing much of a role in checking or exposing corruption in other parts of the system, so they were not forming a new pillar of the NIS, nor (in a phrase from Samoa) a 'traditional integrity system'. Nor did they seem to be concerned about corruption among their members.

\section{Civil Society}

There were differences between reports about the existence, composition and effectiveness of 'civil society'. Some of the differences were about definitions whether to include traditional organisations, or the private sector in it. But there were also real differences about the presence and activity of intermediate groups between government and family. This is important for anti corruption strategies, like TI's which depend on a mobilised civil society

There were no citizens groups reported in Kiribati, in spite of the encouragement that might have been provided by Section 68 of the constitution, requiring local consultation on proposed national legislation. Civil society in Tonga was described as 'poorly developed', as Tongans followed their own family or individual ends.

The reports on Vanuatu, Cook Islands and Solomon Islands by contrast reported a diverse 'civil society' and the first two included traditional leaders within their 
definition. Civil society might of course have corruption problems of its own. Churches in Kiribati and Samoa collected of relatively large amounts of money in donations and spent it on construction work and other activities. The report on Vanuatu warned against NGO complacency - seeing themselves as 'good guys', they had not addressed possibilities of corruption in their own activities. A similar complacency might have affected the churches. Recently the General Assembly of a church in Kiribati had declared corruption in its own ranks 'intolerable' and had laid down procedures. Similarly the report on Samoa finds churches having learned from past problems of poor accounting.

\section{The Private Sector}

TI has succeeded in enlisting some private sector support for the campaign against corruption, and in recasting the private sector as a victim as well as perpetrator. However the NISPAC the reports point to the small size of the private sector, its dependence on government expenditure, its lack of self-organization and the popular perceptions that it is something foreign and exploitative. In Marshall Islands the private sector 'had only really emerged recently'. The Solomons report points the finger at the private sector as a source of political and public service corruption. It blames the Malaysian logging companies that began to harvest timber from customary land in the 1980s, and at some members of the Honiara Chinese business community.

\section{The Media}

The reports consistently show the importance of the media in reporting on corruption. A measure is the personal intimidation faced by journalists and publishers in some, but not all, countries. In Palau for example the radio reporter Alphonso Diaz has had three cars firebombed. An editor in Solomon Islands has been physically intimidated by thugs associated with politicians. A publisher has been threatened with violence in Vanuatu, and publishers have deported from Vanuatu and Palau.

In some countries formal controls are strong. The government either owns the media, or regulates it closely (for example in Samoa the Publishers and Printers act does not allow a journalist to protect sources, and requires they be named). In Tuvalu the report describes how the media were 'ruthlessly and heavily censored'. In Tonga, the government has amended the constitution to allow it to ban newspapers and says it is concerned about scandal concerning the royal family in its recent attacks on freedom of the press. Government motives in muzzling the press, of course, go wider a simple desire to cover up corruption.

However, a privately owned press is not necessarily more critical In Solomon Islands the press was said to be 'free but docile'. Its 'narrow ownership base', and publisher's links within the elite, led to self-censorship. Paradoxically, the government owned SIBC provided more persistent independent criticism.

\section{Comparisons between the NISPAC and Doig/ Mc Ivor studies}

Doig and McIvor found that the NIS 'pillars' were in place, but often failed to do what they were supposed to (2003: 321). NISPAC found the same - in fact the 
country with the most elaborate system, Solomon Islands, had the worst problems. Its NISPAC author talked of 'hollow pillars'. Both sets of reports found failures of the pillars to police themselves, let alone act as checks on each other.

The executive dominance that Doig and McIvor found in their 18 countries was less marked in the NISPAC countries, though the Tuvalu report found a government intolerant of criticism, and the Samoa report worried about single party dominance.

Doig and McIvor found democracy often resting on older structures of power, and creating new opportunities for corruption itself, in matters such as party funding, election campaigning, and gaining support in parliament. In some Pacific Island political systems traditional elites are reproducing themselves in the government, as chiefs become Presidents (Amata and his successor Imata Kabua in Marshall Islands). Or legislators behave like chiefs (FSM). Education, and in some cases literacy distinguish an urban elite from the majority in the outer islands. There is not much that outsiders can do about corruption within the elite, other than populist outbursts of rage when shops and cars get burned. The internal processes of self-policing within the elite (religious or ideological convictions, or a sense of trusteeship on behalf of the nation) become as important as any domestic checks and balances.

Doig and McIvor found reasons to be cautious about the impact of decentralisation on corruption, particularly in the absence of supervision and trained staff. Decentralisation is often demanded in even the smallest of states. Several NISPAC reports expressed concern about the possibilities of corruption at local level, where supervision was reduced, and the pressures of family and kin might be felt more closely. The report on FSM notes differences in legislation and the incidence of corruption between the federal and state governments. The Tonga report investigates a government away from the centre, in this case Vavau. It notes the additional pressures on police and prosecutor in a small town. The report on Marshall Islands described problems of missing funds, and unreported licensing in the urban local government (MALGOV).

The authors of the NISPAC reports were favourably disposed than Doig and McIvor to 'public sector reform' promoted by donors and international financial institutions, though there were concerns about processes of privatisation, and abuse of new found managerial discretion. Doig and Mc Ivor also pointed to the way corruption might undermine popular trust in government. The NISPAC reports suggested that perceptions are shaped by what has happened in the past. A buccaneering style of politics in Cook Islands and perhaps Samoa seems to have permanently soured people against the political system. Cook Islands Political Review Commission found deep popular alienation from the political process, while the Samoa NISPAC report found continuing suspicion of government.

The author of the Solomon Islands report identifies a particular kind of alienation from the state, which he calls 'insidious tolerance', in which - on the one hand people come to believe any kind of corruption accusation, without looking for evidence, and - on the other hand - accept it as inevitable. This is not some traditional hangover, or example of different cultural understandings, but the learned experience of a period of corruption that began in the 1980s, and intensified in the four years leading up to the RAMSI intervention in 2003. But 'insidious tolerance' does not 
seem to have lead to complete disengagement - the report also reports on a very active civil society in Solomon Islands.

\section{$\underline{\text { Smallness }}$}

Doig and McIvor point to the need to assess corruption in different types of states, including 'small island' states (ibid: 329). The NISPAC study happened to include 12 very small states. The average population of these twelve countries is 103,000 ranging from Solomon Islands with 448,000 to Niue with 1,900 (South Pacific Commission 2000). The median is about 50,000. The two largest states in the region, PNG and Fiji had already been separately surveyed (Fiji in Doig and McIvor's project, and PNG separately). The Polynesian and Micronesian islands are mostly atolls, with very small land areas (and hence high population densities, even if their absolute population size is small). How much is the pattern of corruption and anti corruption identified in NISPAC to do with these countries' smallness?

The 12 NISPAC countries were not selected because they were small, and smallness is not a particular issue in the NIS model. Their selection had more to do with Australian regional interests, and the absence of TI groups to coordinate or fund research in all but two of them. Nevertheless, the NIS approach expects to find a gap between theory and practice, and to provoke the search for an explanation. 'Political will' is often offered as an explanation, but 'size' might well be another. It might be a positive or a negative, for corruption, and its prevention. It is often remarked that the two 'success stories' in anti corruption activity, Hong Kong and Singapore, are city states - through each with populations and levels of development large by Pacific standards.

There is a significant correlation between population size and TI's Corruption Prevention index, which ranks countries according to how corrupt they are perceived to be. The perceptions are those of firms that advise investors on 'political risk' and smaller countries tend to be perceived of as less corrupt (Knack and Azfar 2003). The correlation could be related to their tendency to trade more than larger ones (Brautigam and Woolcock 2001: 9). Studies of the politics and government of small states might suggest other explanations (eg Warrington 1998). The NIS study of Fiji, part of Doig and McIvor's sample, suggested that people may be reluctant to report corruption where everyone knows everyone. But among what Herbert Simon called the 'proverbs of administration', there is usually a plausible counter argument: where everyone knows what is going on, it is less easy to avoid detection, and shaming.

In the case of the CPI, Knack and Azfar (2003) argue that the correlation is a spurious result of the availability of data. The CPI is constructed from pre-existing reports of the country risk analysts. These analysts report on well and badly governed large countries, and on well-governed small countries, but tend to ignore badly governed small ones. As TI's index swells to include more smaller badly governed countries, the correlation between population size and corruption, they argue, will disappear. Papua New Guinea, for example, recently joined the index, after its NIS study was done. It was ranked at 102 of 145 countries, tied with Eritrea, Philippines, Uganda, Vietnam and Zambia. 
The NISPAC found the worst corruption problems in Solomon Islands, the largest in terms of land area, and the most populous of this group of the small. In this case the link between population, land area and corruption was probably through the forest industry where the report found an explosion of corruption as foreign timber companies bribed intermediaries to get access to timber. But to really disengangle the effect of smallness from other factors we would have to include bigger spread of countries, large and small.

An earlier study of corruption in the South Pacific (Larmour 1997) found a link between smallness and corruption in the trade in tokens of sovereignty. While constitutionally independent, small states depend heavily on bilateral aid donors and international organisations to fund their functions. In this sense they are what Jackson (1990) called 'quasi states'. These international relations provide openings and opportunities for corruption, just as recently they have become conduits for the promotion of anti corruption.

\section{Trade in Tokens of Sovereignty}

One answer to the absence of resources is to trade in the tokens of sovereignty itself postage stamps, passports, and in the case of Tuvalu, an internet domain name. The NISPAC report describes how in Tuvalu, officials and ministers have attempted to market the domain name, ".tv" , that the country owns as a member of the relevant international organisation. For a while the country was also trading on different rates for international telephone lines as a staging point for phone sex calls originating, and being heard, in the US.

In a postmodern way the country is a country in name only, but that name is a commmodity. It is fertile ground for corruption. In Cook Islands in the 1970s, for example, the state agency charged with selling postage stamps to collectors (rather than people posting letters in Cook Islands) became a slush fund for the government's election campaigning. The sale of passports was the founding issue for Tonga's pro Democracy movement, and there have been scandals over passport sales in Fiji and Samoa. There is often a thin line between individual misbehaviour by officials and ministers, or legal government projects to fast-track investment by offering citizenship.

Similar issues arise for offshore financial centres, which (for example) Britain encouraged Vanuatu to set up in the 1970s, in the absence of prospects for domestic revenue. Cook Islands OFC was an issue in a long running 'winebox' scandal in New Zealand, over a New Zealand company's use of accounts in Cook Islands to reduce its tax burden. In the late 1990s the OCED became worried about leakage of taxes to OFCs. More recently, since 9/11 their concern has been sharpened over money laundering.

Very small countries also may lack opportunities to invest their own resources domestically. When they must invest abroad, beyond domestic supervision, they may make wrong or corrupt decisions. Kiribati has a well-managed overseas investment arm, though is always under pressure to consume earnings from it, rather than reinvest it. Tuvalu successfully proposed to donors that they put their aid into a fund that would provide a regular stream of income to the government (Duncan Hunt and 
Larmour 1995). Nauru, however, has a longer tradition of ministerial involvement in day to day offshore investment decisions where again it is hard to distinguish individual acts of corruption from those of mismanagement, or poor collective judgement. Certainly its offshore investments have been plagued with suspicion of kickbacks, and corruption by middlemen and advisers, leading to the fiscal crisis that has provoked intervention by Australian officials.

\section{What is to be done?}

The authors of the NISPAC reports were academics and former officials selected, by and large, for their knowledge of particular countries, rather than any particular expertise in corruption, or its prevention. The remedies they came up with tended to be fairly standard, like the 'first wave' of reforms in eastern Europe (Michael 2004): an independent commission, a national strategy, and so on. Yet the internal evidence from the reports is at cross-purposes with their recommendations for stronger political parties, an ICAC, coalition strategies and more accountability.

\section{$\underline{\text { Political Parties? }}$}

Several reports, despairing of the fluidity of non-partisan politics, and vote buying in elections, propose that strong political parties would help reduce opportunities for corruption. Ideologically based parties might create a reason for voters to choose apart from the material benefits promised by candidates. Once elected, parties might limit the maneuvering and promising required to stitch together a government, and the flow of resources across the floor to maintain 'confidence' in the government. They might reduce the tendency of legislatures to close ranks outside criticism, for example from auditors of their travel expenses. PNG, for example, has introduced legislation designed to strengthen parties against floor crossers, and independent candidates.

However the Samoa report also points to the contrary danger of too strong a party. The Human Rights Protection Party has now been in power since the late 1980s, and the report expresses fear that its dominance may allow corruption to flourish unchecked. Parties suffer their own internal vulnerability to corruption over such matters as misappropriation of funds, influence peddling, and vote buying (as recent scandals in Germany have shown). The Kiribati report mentioned concern about foreign funding of parties. Party advisers regularly try to interfere with public service decisions, as in Vanuatu.

\section{$\underline{\text { An ICAC? }}$}

Several reports recommended an ICAC on the Hong Kong or Sydney models. Doig (1995) and others have argued for the usefulness of an ICAC as a focus of anti corruption activity, and donor support for it. Creating them helps symbolise government commitments. But other evidence in the reports does cast doubt on the value of independent stand-alone agencies, such as auditors general ombudsmen or leadership code commissioners in the region. 
The reports' discussions of election commissions also cast doubt about stand-alone independent institutions from the other direction. They generally find elections to be clean, in spite of the absence of independent election commissions in most countries.

As we have seen, senior appointments in these countries are often made to reward political support - the position of anti-corruption commissioner may end up being just such a resource. At a minimum, parliament and the executive, rather than overseeing each other, have a common interest in appointing independent bodies that will not make waves.

Maybe each of these independent institutions could and should do better. Vanuatu's feisty leadership code commissioner may set an example, rather than acting as the exception that proves the rule. Next time, perhaps, the designers will get it right, but the overall record suggests caution in creating yet another independent agency.

There is also an opportunity cost in creating new institutions - resources, including political attention and donor support, come from somewhere else that suffers. Second, the resources available to such agencies are relatively small. They must pick and choose their fights. The bulk of anti corruption activity, or inactivity, continues to take place in large spending departments, the public service and the police. Third, as a new pillar, they generate new problems of horizontal accountability. They get caught in turf wars, and must ensure their own internal integrity.

\section{Coalition strategies?}

TI has a lively organisation in Vanuatu, and a newly formed group in Solomon Islands. There was interest expressed at public forums in Tonga and Samoa, where early drafts of the country reports were discussed. TI's global strategy is based on the idea of coalitions of public, private and NGO sectors. It doubts that governments alone can reform themselves. It also emphasizes education and prevention over investigation and prosecution - the latter involving legal powers in any case not available to NGOs. What do the reports suggest about the prospects for such a strategy?

First, civil society - depending on how broadly it is defined - is unevenly developed between countries. A major component, the churches, has been reluctant to criticise governments. In Samoa and Kiribati they have also recognized the need to put their own house in order.

Second both civil society and the private sector is relatively disorganized. The Vanuatu reports criticize civil society for lack of coordination and ' reinventing the wheel'. The Tonga report finds Tongans particularistic, and reluctant to join organizations outside the family. The private sector has not shown much capacity for self-organisation, except perhaps in Tonga. There is a Chamber of Commerce in FSM, but Tuvaluan business would be reluctant to pay the fees necessary to join one.

\section{Accountability and Transparency?}

In Marshall Islands accountability was seen as the necessary precondition for dealing with corruption. Votes of No Confidence, for example, are a way in which the 
legislature in Westminster systems is meant to hold the executive to account. In parliaments without strong party or ideological identifications, however, the threat of such a vote may become, as it has in Solomon Islands, simply another way for nongovernment MPs to extract resources or positions from the executive. Similarly the reports on Solomon Islands and Cook Islands notice the bad effects of putting Permanent Secretaries or Heads of Ministries on contracts, making them more accountable to ministers (at the cost, they say, or independence and competence)

The international community, including of course TI, strongly promotes transparency. However, the reports show that not all corruption is hidden, particularly petty corruption, and the corruption associated with elections, or deals on the floor of parliament. Several reports point out that in small-scale societies everyone knows - or thinks they know - what is going on. Opacity is not the problem, but different understandings, reluctance or intimidation. However, when that activity takes place abroad - during trips overseas, or in offshore investments - that steady local scrutiny is absent, though the gossip continues.

The reports generally suggest accountability and transparency may be of limited use if civil society or ordinary members of the public aren't willing or able to do much about what is going on. In Vanuatu many people saw corruption as something only associated with the modern urban sector and of little importance to them. In other cases the public seems complicit: in Tuvalu, for example, ministers are subject to pressure from voters to change shipping schedules in their favor. Several reports find the public acquiescent, cynical or merely forgiving.

\section{$\underline{\text { Conclusions }}$}

There seems to be a distinctive pattern of corruption and anti corruption in the Pacific Islands, compared to the more heterogeneous group of countries studied by the same methods by Doig and McIvor. Some, but not all of those differences, may have to do with their smallness in population and land area. Smallness generates particular risks of corruption (for example in offshore activities) and also particular types of anti corruption activity (for example involving the regional and multilateral organisations of which they are members). The principles underlying the NIS - of mutual supervision between various institutions, checks and balances, independent officesseem to run into difficulty when applied at a very small and personal scale. Proliferating offices may be impossible to resource or staff adequately, and independence more difficult to achieve. Other anti-corruption principles than 'checks and balances' may have to be looked for. Anti-corruption activity may also become more international. RAMSI has introduced a new layer of outside involvement in anti corruption, at least in Solomon Islands. Since RAMSI began eighty-eight police officers have been charged with corruption, murder or other serious crimes and about 25\% of the force removed from office (Wainwright 2005: 3). No deadline has been set for RAMSI's withdrawl, and officials talk of it being in place for 'five to ten years'. 


\section{$\underline{\text { References }}$}

Brautigam, D., and M. Woolcock, 2001 'Small States in a Global Economy' Discussion Paper No 2001/37 WIDER UNU

Doig, A., 1995 'Good government and sustainable anti-corruption strategies: a role for independent anti-corruption agencies?' Public Administration and Development 15: $151-165$

Doig, A. and S. McIvor 2003 'The National Integrity System: Assessing Corruption and Reform’ Public Administration and Development 23: 317-332

Downer, A., 2005 ‘Australian Aid: An Integrated Approach’ Thirteenth Annual Statement to Parliament on Australia’s Aid Program. Canberra: AusAID

Financial Action Task Force 2005 http://www.fatf-gafi.org/ downloaded 10 May 2005

Jackson, R., 1990. Quasi States: sovereignty, international relations and the Third World. Cambridge Studies in International Relations 12.

Larmour, P., 1997. 'Corruption and Governance in the South Pacific' Pacific Studies 20 (3): 1-17

Larmour, P., 2000. 'Issues and Mechanisms of Accountability: Examples from Solomon Islands’ State Society and Governance in Melanesia Working Paper 00/1 Canberra: RSPAS, ANU

Michael, B., 2004. 'The Globalization of Anti-Corruption Policies: the Diffusion of Best Practices and the Role of Knowledge Management' in D. Levi-Faur and E. Vigoda-Gadot, eds International Public Policy and Management: Policy Learning Beyond Regional, Cultural and Political Boundaries New York: Marcel Dekker pp 325-350

Nelson, J., 1984. The Political Economy of Stabilization: Commitment, Capacity, and Public Response. World Development 12 (10):983-1006.

O’Callaghan, M 2004 'Corrupt force at the end of the line' The Australian March 8 p 15

Pope, J., 2000 TI 'Source Book 2000 Confronting Corruption: The Elements of a National Integrity System’ http://www.transparency.org/sourcebook/index.html

So’o, A., 1998 'The Price of Election Campaigning in Samoa' in P. Larmour Ed Governance and Reform in the South Pacific Canberra: National Centre for Development Studies, Australian National University pp 289-304

Transparency International 2005 http://transparency.org/activities/nat_integ_systems/country_studies.html (downloaded10 May 2005) 
Wainwright, E., 2005 'How is RAMSI Faring: Progress, Challenges and Lessons Learned’ Canberra: Australian Strategic Policy Institute

Warrington, E., 1998 'Introduction: Gulliver and Lilliput in a new world order; the impact of external relations on the domestic policies and institutions of micro-states' Public Administration and Development 18: 101-105 